\title{
A re-assessment of the safety of silver in household water treatment: rapid systematic review of mammalian in vivo genotoxicity studies
}

\author{
Lorna Fewtrell ${ }^{1}$, Batsirai Majuru ${ }^{2}$ and Paul R. Hunter ${ }^{2^{*}}$
}

\begin{abstract}
Background: Despite poor evidence of their effectiveness, colloidal silver and silver nanoparticles are increasingly being promoted for treating potentially contaminated drinking water in low income countries. Recently, however, concerns have been raised about the possible genotoxicity of particulate silver.

Objectives: The goal of this paper was to review the published mammalian in vivo genotoxicity studies using silver micro and nanoparticles.

Methods: SCOPUS and Medline were searched using the following search string: ("DNA damage" OR genotox* OR Cytotox* OR Embryotox*) AND (silver OR AgNP). Included papers were any mammalian in vivo experimental studies investigating genotoxicity of silver particles. Studies were quality assessed using the ToxRTool.

Results: 16 relevant papers were identified. There were substantial variations in study design including the size of silver particles, animal species, target organs, silver dose, route of administration and the method used to detect genotoxicity. Thus, it was not possible to produce a definitive pooled result. Nevertheless, most studies showed evidence of genotoxicity unless using very low doses. We also identified one human study reporting evidence of "severe DNA damage" in silver jewellery workers occupationally exposed to silver particles.

Conclusions: With the available evidence it is not possible to be definitive about risks to human health from oral exposure to silver particulates. However, the balance of evidence suggests that there should be concerns especially when considering the evidence from jewellery workers. There is an urgent need to determine whether people exposed to particulate silver as part of drinking water treatment have evidence of DNA damage.
\end{abstract}

Keywords: Silver, Nanoparticles, Genotoxicity, DNA damage

\section{Background}

Household point-of-use (POU) treatment is being widely promoted as an interim measure to improve the quality of drinking water in low income settings where consumers do not have access to improved drinking water supplies. There is a range of different technologies that are being promoted by different agencies and nongovernmental organizations that can be broadly categorised as disinfection or filtration technologies $[1,2]$. Within this diverse range of technologies colloidal silver

\footnotetext{
* Correspondence: Paul.Hunter@uea.ac.uk

${ }^{2}$ Norwich Medical School, University of East Anglia, Norwich NR4 7TJ, UK Full list of author information is available at the end of the article
}

(Ag) is being promoted as a primary water disinfectant, both silver nitrate $\left(\mathrm{AgNO}_{3}\right)$ and silver nanoparticles (AgNP) are being added to the surface of ceramics and AgNP is being investigated as an adjunct to filtration technologies in a wide number of experimental systems [3-5]. Typically, nanoparticles are small particles with one dimension being $100 \mathrm{~nm}$ or less. Colloidal Ag consists of micro and nanoparticles of silver, typically in the range of 2-500 $\mathrm{nm}$, dispersed throughout another substance [6].

Among those promoting the use of colloidal Ag or AgNP there is the general assumption that this product is safe in humans. The World Health Organization 
(WHO) Guidelines for Drinking-water Quality currently do not have a guideline value for $\mathrm{Ag}$ in drinking water, but indicate a concentration of $0.1 \mathrm{mg} / \mathrm{L}$ which could be tolerated without risk to health [7]. However, this value was determined as being unlikely to cause argyria (a discolouring of the skin due to silver deposition) and took no consideration of possible adverse effects associated with AgNP, nor did it consider any potential genotoxicity.

Based on a study of a woman with argyria it was estimated that following consumption of silver acetate, up to $18 \%$ of the dose was absorbed [8]. From animal studies, AgNP adsorption is less than that for Ag salts, suggesting a lower bioavailability for AgNP [6].

After absorption Ag and AgNP are widely distributed through the body. Retention of Ag and AgNP varies between different organs, although retention in the brain and testes seems to be particularly strong [9].

A review of the safety of Ag, colloidal Ag and AgNP was published by Hadrup and Lam [6]. They reported that a range of dose-dependent toxic effects have been described in experimental animals including: "weight loss, hypoactivity, altered neurotransmitter levels, altered liver enzymes, altered blood values, enlarged hearts and immunological effects". However, most of these effects were seen at doses well above levels likely to be consumed in water, even with the use of $\mathrm{Ag}$ as a primary water disinfectant. Nevertheless, they still recommended a Tolerable Daily Intake (TDI) value of $2.5 \mu \mathrm{g} / \mathrm{kg}$ of body weight/day.

An area of further interest is whether exposure to $\mathrm{Ag}$ and AgNP is associated with genotoxic effects. Hadrup and Lam concluded that Ag only has limited genotoxic effects [6]. Their conclusions, however, were based on a relatively small number of studies, two of which were concerned with $\mathrm{Ag}$ halide salts and two with AgNP. Neither of the two studies of Ag halides found evidence of genotoxicity. Of the two studies with AgNPs one found no micronucleus induction following 28 days of oral $60 \mathrm{~nm}$ silver nanoparticle administration [10]. The other study reported micronucleus induction in the TK6 lymphoblastoid cell line of rats following incubation with $5 \mathrm{~nm}$ silver nanoparticles at a concentration of $25 \mu \mathrm{g} / \mathrm{mL}$ [11].

In a substantially more detailed review of the genotoxicity of a wide range of nanoparticles, Magdolenova and colleagues included 13 different Ag microparticles and AgNP publications [12], of which one was an in vivo study [10]. Of the in vitro studies detailed, 9 used human cells or cell lines. A variety of $\mathrm{Ag}$ particle sizes (3 to $>200 \mathrm{~nm}$ ), coatings (including none, starch, polysaccharide and polyvinyl pyrrolidone), doses $(0.01 \mu \mathrm{g} / \mathrm{mL}$ to $100 \mathrm{mg} / \mathrm{mL}$ ), exposure periods and genotoxicity assay methods were used in the identified studies. Every in vitro mammalian cell-based study found AgNP to be genotoxic. Although many of the studies tested only relatively high concentrations of AgNP (up to $100 \mu \mathrm{g}$ / $\mathrm{mL}$ ), some studies used much lower concentrations and evidence of genotoxicity was found in human bronchial epithelial cells using both the micronucleus and comet assays at levels as low as $0.01 \mu \mathrm{g} / \mathrm{mL}$ [13].

Since the publication of these reviews, there has been a substantial number of papers published investigating the genotoxicity of silver AgNP in a wide variety of both in vivo and in vitro models. While the general consensus from the in vitro studies is that AgNP are genotoxic, the most important evidence would come from the in vivo studies. Thus, in order to investigate whether or not AgNP and, therefore, colloidal silver are likely to be genotoxic to humans and present a risk to health through its use in household drinking water treatment, we conducted a systematic review of in vivo mammalian studies administering AgNP and Ag microparticles.

\section{Methods}

Searches were run in both SCOPUS and Medline using the following search string: "DNA damage" OR genotox* OR Cytotox* OR Embryotox*) AND (silver OR AgNP). Initial searches were run on 15 November 2015 and then again on 29 February 2016. Searches were run without restrictions for date or language.

Inclusion criteria were any in vivo experimental study investigating genotoxicity of silver particles in mammalian models. In vitro studies in cell culture were excluded as were any in vivo studies in nonmammals such as fish, insects or helminths. In addition, we included any observational studies of genotoxicity in humans exposed to silver particles. Data were extracted from included papers into an excel spreadsheet by one author and checked by another. Data extracted included study identifier, year of publication, description of silver nanoparticles, the animal model used, the target organs, route of administration of nanoparticles, the study design, doses and frequency of administration, the time to a sacrifice after administration, method of detecting genotoxicity, whether genotoxic effects were identified and a short narrative summary of the study conclusions. The basic outcome measure was whether or not genotoxic effects had been identified.

The selected papers, which used either the comet assay or the micronucleus assay (both of which have Organisation for Economic Co-operation and Development $[\mathrm{OECD}]$ test guidelines) were subjected to a reliability assessment using ToxRTool [14], which results in each paper being scored out of 21 and the assignment of one of four categories (based on a previous paper by Klimisch and colleagues [15], namely: 
1. Reliable without restrictions (score of 18 and above);

2. Reliable with restrictions (score of 13-17);

3. Not reliable (score of 12 and below);

4. Not assignable.

In order to be considered reliable (i.e. category 1 or 2 ) the minimum score must be achieved and the report must achieve all of the 8 'red' (i.e. essential) criteria. The results are shown as the overall category followed by the score in brackets and, where applicable, the reason the study was downgraded to not reliable.

\section{Results}

The initial search yielded 3191 references which were scanned by title and abstract. Of these references, 163 papers were identified for further study (Fig. 1). We finally identified 16 papers that investigated in vivo genotoxicity of silver nanoparticles, though one paper reported using both single and multiple dose study designs and we have considered these separately; making 17 studies in total. Those studies (15) reporting use of either the micronucleus assay or the comet assay are outlined in Table 1. An additional two studies are described in Table 2. The first paper identified was published in 2008 and the second in 2009 and then no more until 2011. There has been a substantial increased interest in this topic with half of the papers ( 8 of 16) being published from 2014 onwards.

The included investigations showed substantial variation in study design including choice of the size of silver particles, animal species, target organs, silver dose, route of administration and the method used to detect genotoxicity.

The AgNP ranged in size from $<10 \mathrm{~nm}$ (6 studies) up to $200 \mathrm{~nm}$ (2 studies - microparticles), with 3 studies testing different AgNP sizes. The majority of studies did not explicitly state whether the AgNP used were naked or capped. When stated, capping/stabilising agents include poly styrene-co-maleic anhydride and PVP. Seven studies used rats and 10 mice. Target organs included bone marrow (7), peripheral blood (4), spleen (2), testes (2), lung (1), skeletal muscle (1) and kidney (1). In addition, one study looked at the impact on the offspring of pregnant test animals.

Of the 17 studies, 6 administered the doses by intraperitoneal injection, 4 by intravenous injection, 1 by inhalation and 6 orally. Most studies (9) gave just a single dose but the remaining 8 studies gave repeated doses of AgNP. For the repeated dosing experiments the duration and frequency varied substantially (Table 3 ). The doses administered to the animals varied by as much as 5 logs, ranging from 0.01 to $1000 \mathrm{mg} / \mathrm{kg}$. The comet assay was

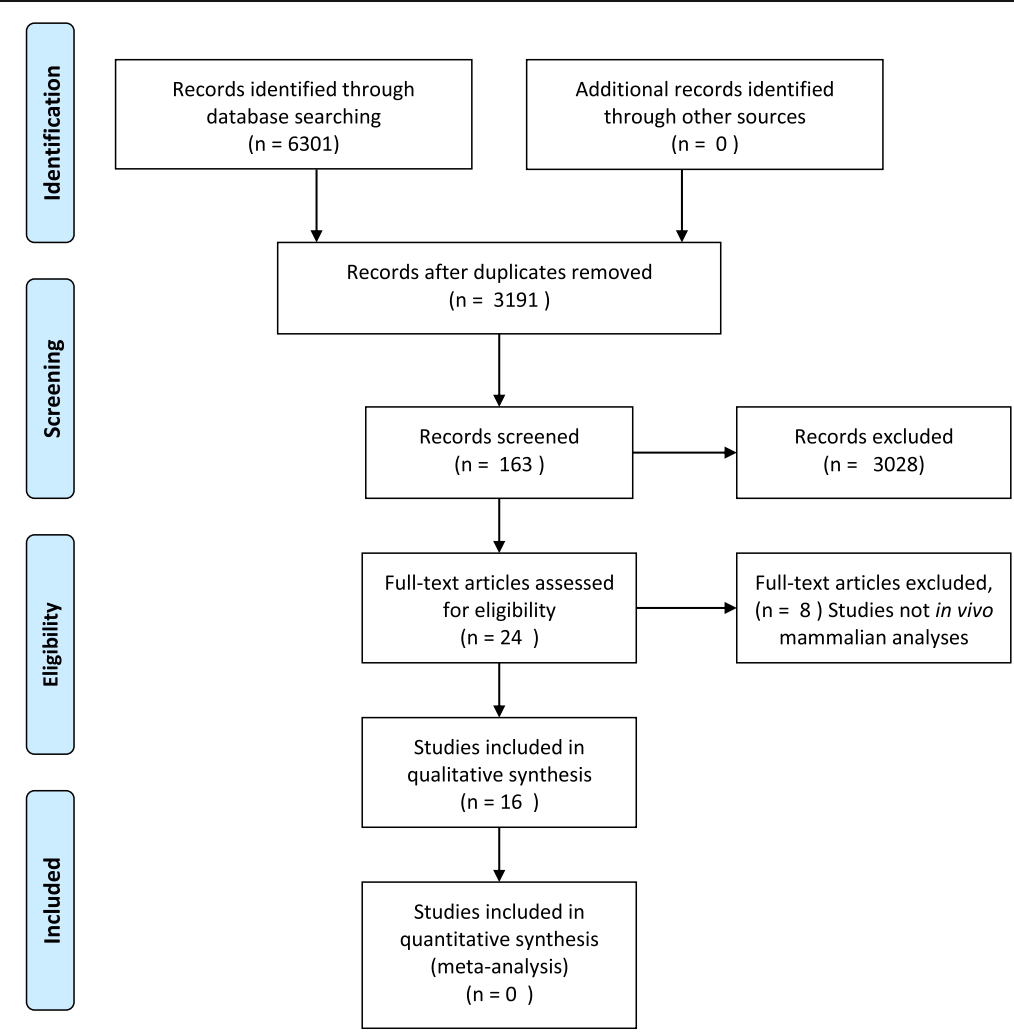

Fig. 1 PRISMA Flow Diagram of in vivo mammalian genotoxicity studies of silver nanoparticles [34] 
Fewtrell et al. Environmental Health (2017) 16:66

Page 4 of 9

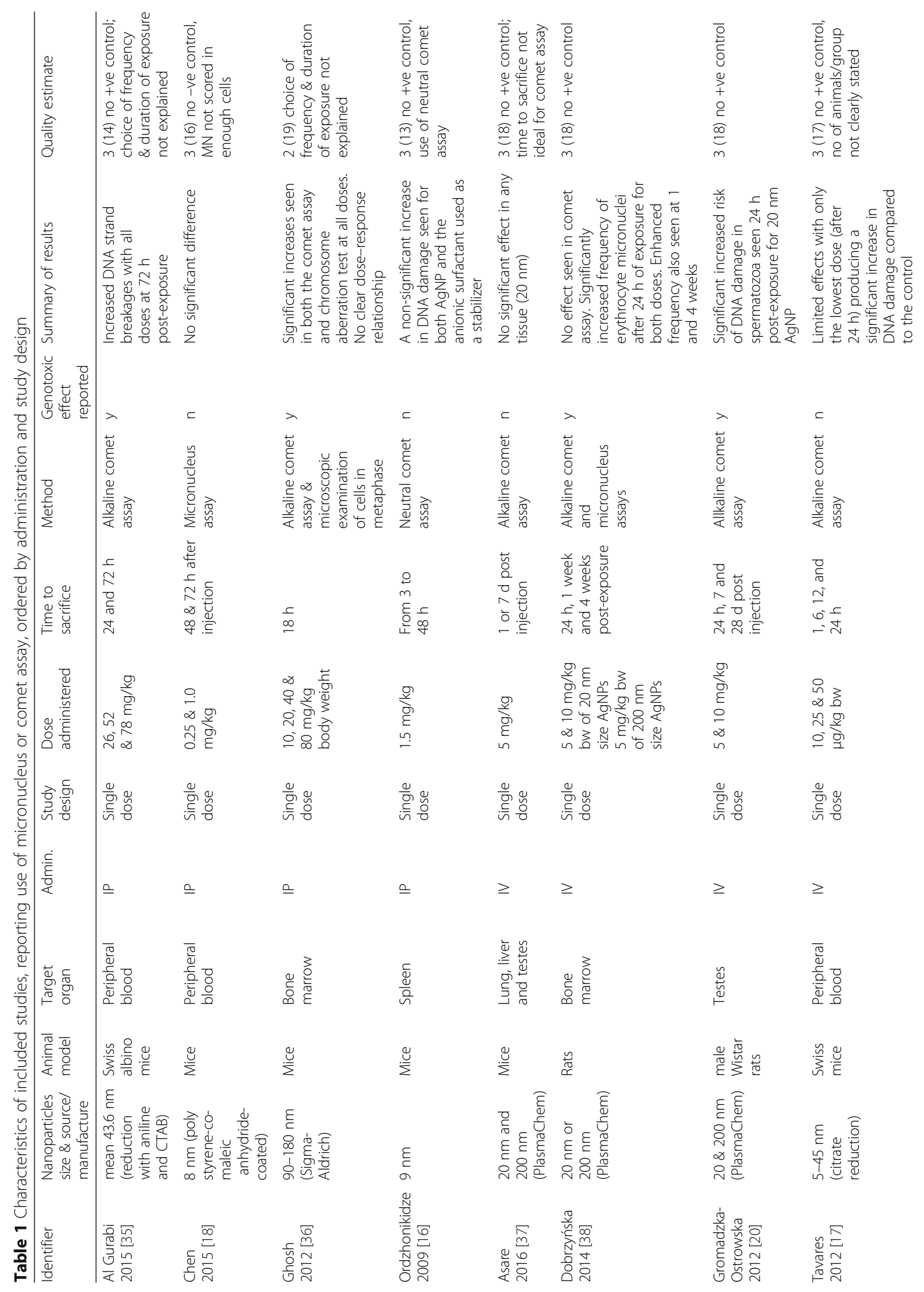




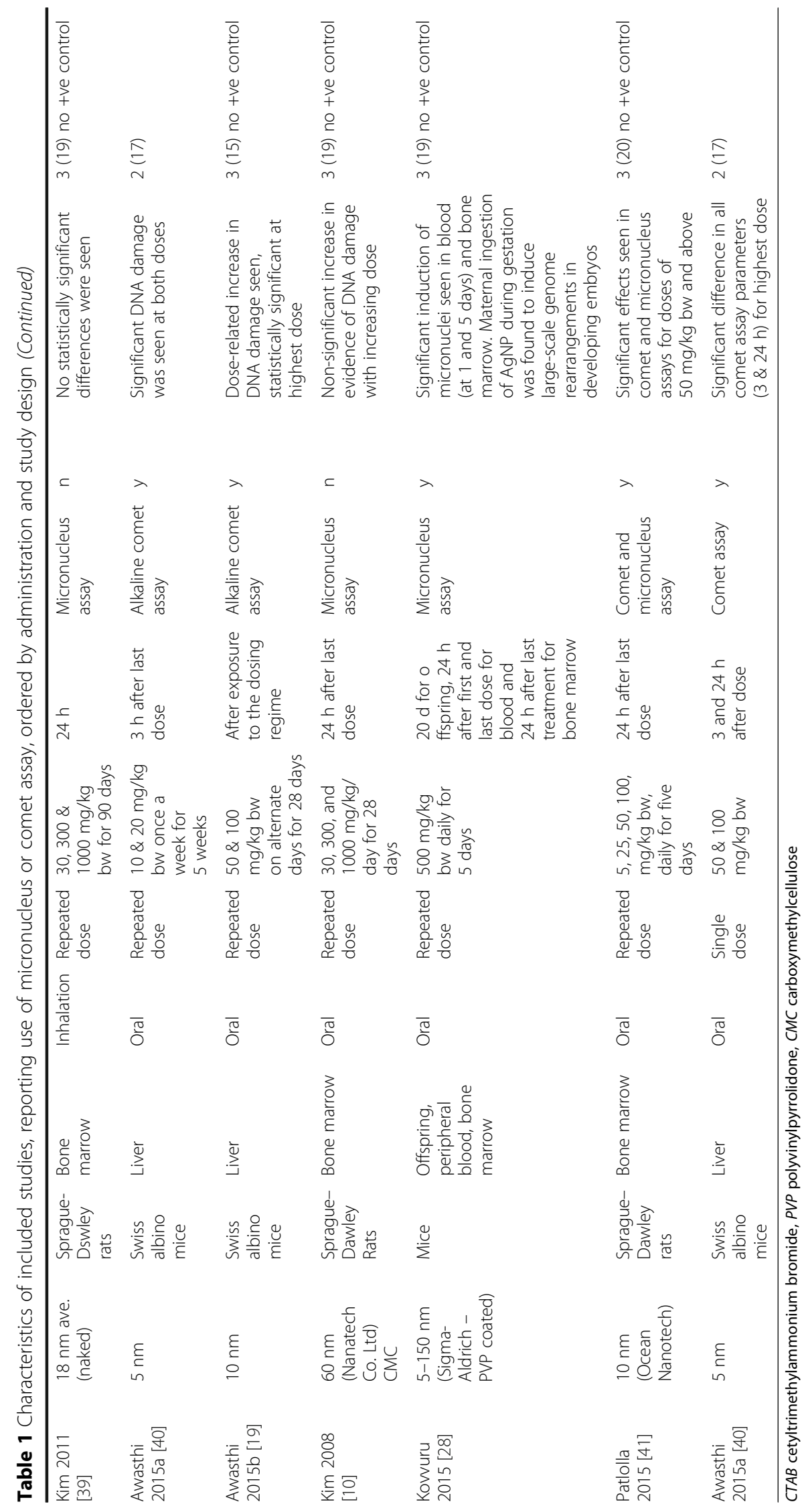


Table 2 Characteristics of included studies using tests other than micronucleus and comet assay

\begin{tabular}{|c|c|c|c|c|c|c|c|c|c|c|}
\hline Identifier & Nanoparticles & $\begin{array}{l}\text { Animal } \\
\text { model }\end{array}$ & Target organ & Admin. & $\begin{array}{l}\text { Study } \\
\text { design }\end{array}$ & $\begin{array}{l}\text { Dose } \\
\text { administered }\end{array}$ & $\begin{array}{l}\text { Time to } \\
\text { sacrifice }\end{array}$ & Method & $\begin{array}{l}\text { Genotoxic } \\
\text { effect } \\
\text { reported }\end{array}$ & Summary of results \\
\hline $\begin{array}{l}\text { El Mahdy } \\
\text { [42] }\end{array}$ & $\begin{array}{l}\text { mean } 8.7 \mathrm{~nm} \\
\text { (chemical } \\
\text { reduction - } \\
\text { PVP } \\
\text { stablization) }\end{array}$ & $\begin{array}{l}\text { Albino } \\
\text { rats }\end{array}$ & Liver & $\mathbb{I P}$ & $\begin{array}{l}\text { Repeated } \\
\text { dose }\end{array}$ & $\begin{array}{l}1,2 \text { and } \\
4 \mathrm{mg} / \mathrm{kg} \\
\text { bw daily } \\
\text { for } 28 \text { days }\end{array}$ & $\begin{array}{l}\text { At end } \\
\text { of } \\
\text { study }\end{array}$ & $\begin{array}{l}\text { Microscopic } \\
\text { examination } \\
\text { of cells in } \\
\text { metaphase }\end{array}$ & y & $\begin{array}{l}\text { Increased chromosomal } \\
\text { aberrations, significant } \\
\text { at } 2 \text { and } 4 \mathrm{mg} / \mathrm{kg} \text { bw }\end{array}$ \\
\hline $\begin{array}{l}\text { Katsnelson } \\
\text { [43] }\end{array}$ & $\begin{array}{l}\text { mean } 49 \text { nm } \\
\text { (laser } \\
\text { ablation - } \\
\text { naked) }\end{array}$ & Rats & $\begin{array}{l}\text { Liver, bone } \\
\text { marrow, } \\
\text { spleen, kidney, } \\
\text { peripheral } \\
\text { blood \& } \\
\text { skeletal muscle }\end{array}$ & IP & $\begin{array}{l}\text { Repeated } \\
\text { dose }\end{array}$ & $\begin{array}{l}10 \mathrm{mg} / \mathrm{kg} \\
3 \text { times a } \\
\text { week for } \\
\text { up to } 20 \\
\text { injections }\end{array}$ & $?$ & RAPD-test & y & $\begin{array}{l}\text { Significantly increased } \\
\text { evidence of DNA } \\
\text { fragmentation in liver, } \\
\text { bone marrow, spleen, } \\
\text { kidney and peripheral } \\
\text { blood cells }\end{array}$ \\
\hline
\end{tabular}

used in 11 investigations, the micronucleus assay in 6, 2 used microscopy of cells in metaphase to look for chromosomal abnormalities and 1 used the randomly amplified polymorphic DNA (RAPD) test.

Of the 17 studies, 11 reported evidence of genotoxicity (Tables 1 and 2). Table 1 outlines the studies using in vivo micronucleus or comet assays, which are the basis of the current OECD guidelines for in vivo genotoxicity testing. Table 2 list the studies using other methods. Where multiple cell/tissues were examined and some were found not to show evidence of genotoxicity, we have only referred to the significant findings in the Table. Of the 6 studies that reported not finding evidence of an in vivo genotoxic effect of AgNP, 2 were the first such studies to be reported $[10,16]$. Three of the negative studies used lower concentrations (in a single dose) than the most of the other studies $(0.01,0.025$ and $0.05 \mathrm{mg} / \mathrm{kg}$ - [17]; 0.25 and $1 \mathrm{mg} / \mathrm{kg}$ - [18] and $1.5 \mathrm{mg} /$ $\mathrm{kg}$ - [16]). While Kim et al. suggested that their results were not statistically significant they did observe a nonsignificant trend in micronucleus formation in males with increasing dose and an increased effect in females at 2 of the 3 doses [10]. Consequently, mammalian in vivo evidence of genotoxicity was reported in the majority of studies, providing that a sufficient dose of AgNP were administered.

DNA deletions and breakages were reported particularly frequently across the studies, with the most worrying being the detection of large DNA deletions in developing embryos, albeit after a very large oral dose of $500 \mathrm{mg} / \mathrm{kg}$ daily for five days in pregnant mice [19]. In

Table 3 Summary multiple dosing regimen

\begin{tabular}{lll}
\hline Frequency of dosing & Duration of dosing & Number of studies \\
\hline Daily & 5 days & 2 \\
Daily & 28 days & 2 \\
Alternate days & 28 days & 1 \\
3 times a week & 20 injections & 1 \\
Weekly & 5 weeks & 1 \\
\hline
\end{tabular}

addition, a significant risk of DNA damage in spermatozoa was reported by Gromadzka-Ostrowska et al. further raising concerns about damage to future generations [20].

The selected papers were subjected to a reliability assessment and, as can be seen from Table 1, only 2 studies were classed as reliable (with or without restrictions). The principal reason for the 'not reliable' classification was the absence of a positive control, which is recommended for both the in vivo mammalian alkaline comet assay and the in vivo mammalian micronucleus test $[21,22]$. If the fact that (in the majority of cases) assays generally gave a positive result means that a positive control is not a requirement, then a further 7 studies can be classified as reliable. The two remaining studies (Table 2) could not be rated for quality as they had not used a method for which there are internationally accepted guidelines.

One further paper is worthy of note because it is the only study, so far, to have investigated the possible relationship between DNA damage in humans and silver exposure [23]. These authors investigated evidence of DNA damage in silver jewellery workers who are at risk of inhalation of silver particles. The comet assay was used to investigate DNA damage in mononuclear leukocytes and showed a significant increase in DNA damage in the jewellery workers compared to local controls. While suggestive the findings of the study need to be interpreted with care as there are a number of limitations (including a small number of participants and a lack of direct measurements or estimates of exposure).

We did not find any papers which suggested that in vivo exposure to ionic silver posed a threat of genotoxicity, but those few studies that reported on ionic silver found no effect even from in vitro studies [6].

\section{Discussion}

We have presented the first systematic review of in vivo genotoxicity studies of AgNP in mammalian models. The majority of the identified studies reported evidence of genotoxicity and the negative studies were generally those using single small doses. The potential genotoxic 
effect was supported by a single human observational study, which reported evidence of the accumulation of severe DNA damage in jewellery workers who were occupationally exposed to silver particles and AgNP. While, as noted by the European Food Safety Authority (EFSA) [24] the studies do not allow a definitive assessment of human genotoxic hazard associated with oral exposure to AgNP, we feel that the results are suggestive that such a risk may exist.

In our review, we found substantial variation in study design including choice of the size of silver particles, animal species, target organs, silver dose, route of administration and the method used to detect genotoxicity. There are also numerous different methodologies for the synthesis of AgNP they can, for example, be produced in a range of sizes and shapes and stabilised with a variety of capping agents; these factors alone make generalisations difficult. In addition, some capping agents and manufacturing contaminants may be toxic in their own right [25], although this does not appear to have been investigated in relation to genotoxic effects

The studies used a range of assay methods, not all of which may comply with the current OECD recommendations. While there has been some debate in the literature on the most appropriate methods for genotoxicity testing of nanoparticles (e.g. Warheit and Donner [26]), recent expert opinions have not suggested a move away from existing protocols [21, 22].

A further complication in relation to applying the findings to oral ingestion is the high proportion of studies administering AgNP via injection (intravenous and intraperitoneal); given that Ag absorption is likely to be lower following oral ingestion it would not be surprising if studies using injected silver over-estimate risk from ingestion. It should be noted, however, that 5 of the 6 studies using oral administration showed statistically significant genotoxic effects, and the one study reporting negative results showed a non-significant increase in DNA damage with increasing dose [10].

The comet assay is classed as an 'indicator test' because the measured end point may not always lead to a mutation [27]; this raises the issue of whether or not some of the DNA damage described in the reported studies is likely to be reversible. In one study, with relatively low exposure, the DNA damage did appear to be reversible with time [17]. Clearly, DNA repair mechanisms will reduce the genotoxic potential of AgNP. However, it is not certain how effective these repair mechanisms will be in those tissues such as the brain and testes where bioaccumulation of AgNP has been reported to occur. In addition, it is unlikely that "the large DNA deletions" in developing embryos and "irreversible chromosomal damage" in bone marrow described by Kovvuru et al. [28] are transient (although the dose used in this study was particularly high - $500 \mathrm{mg} / \mathrm{kg}$ for 5 days) and the finding of the "accumulation of severe DNA damage" in people occupationally exposed to silver particles certainly suggests that concerns about human safety are real [23]. While it is not possible from this observational study to quantify exposure in the jewellery workers, these findings would suggest that DNA repair mechanisms can be overwhelmed with frequent exposure to silver particles. It is certainly plausible that consumers using colloidal $\mathrm{Ag}$ as the primary drinking water disinfectant or workers adding AgNP to ceramic filters in low income countries would have similar or even greater exposure than the jewellery workers. The limited available evidence indicates that health and safety precautions are not strictly adhered to in the production of ceramic filters in low income countries [29].

The wide heterogeneity in study designs makes it difficult to draw substantial conclusions and, especially, to determine a safe daily exposure to AgNP. Without being able to state a safe exposure limit, it is not possible to say if exposure to the colloid Ag or AgNP employed in some current household water treatment practices poses a significant risk to human health. However, given that the use of AgNP and colloidal Ag in household water treatment does not appear to be effective at making drinking water safe [30], there is little value in their use and any risks of genotoxicity are consequently intolerable. Given the likely bioaccumulation especially in brain and testes, people using colloidal $\mathrm{Ag}$ as a primary drinking water disinfectant and their offspring may be at high risk of genetic damage. The risks associated with use of AgNP in other matrices, such as ceramic filters, are less clear. There is substantial evidence that AgNP are released from many different supporting matrices [31], but it is not yet possible to say with certainty whether or not such release would be in sufficient concentration to pose a health risk.

\section{Conclusions}

We consider that colloidal Ag should not be promoted as a primary water treatment product as it has little public health benefit and the balance of evidence would certainly suggest that there is at least the possibility of genotoxic and embryotoxic effects. With the current evidence it is not yet possible to determine a safe limit for the oral intake of AgNP or colloidal Ag. Before colloidal Ag or AgNP are used in filter matrices for drinking water treatment, consideration needs to be given to how much silver is likely to be released from the matrix during the life of the filter (eg work by Garboś and colleagues) [32,33]. There is an urgent need for more research on this topic and particularly on whether people using colloidal Ag as a primary drinking water treatment, working with AgNP in filter manufacture in low income countries or using such impregnated filters have evidence of DNA damage. 


\section{Abbreviations}

Ag: Silver; AgNO3: Silver nitrate; AgNP: Silver nanoparticles;

CMC: Carboxymethylcellulose; CTAB: Cetylmethylammonium bromide; EFSA: European Food Safety Authority; OECD: Organisation for Economic Cooperation and Development; POU: Point-of-use; PVP: Polyvinylpyrrolidone; RAPD: Randomly amplified polymorphic DNA; TDI: Tolerable daily intake; WHO: World Health Organization

\section{Acknowledgements}

The authors wish to acknowledge Ruth Bevan for helpful comments on the draft manuscript.

\section{Funding}

No external funding was used.

\section{Availability of data and materials}

All articles from which data collected listed in references.

\section{Authors' contributions}

All authors contributed to study design, $\mathrm{PRH}$ undertook initial literature searches, PRH and LF performed data extraction and initial analyses. All authors contributed to interpretation of findings. PRH wrote first draft of manuscript and all authors contributed to the final manuscript. All authors read and approved the final manuscript.

\section{Competing interests}

The authors declared they have no competing interests.

\section{Consent for publication}

Not applicable.

Ethics approval and consent to participate

Not applicable.

\section{Publisher's Note}

Springer Nature remains neutral with regard to jurisdictional claims in published maps and institutional affiliations.

\section{Author details}

${ }^{1}$ Centre for Research into Environment and Health, University of Aberystwyth Aberystwyth, UK. ${ }^{2}$ Norwich Medical School, University of East Anglia, Norwich NR4 7TJ, UK

Received: 12 January 2017 Accepted: 11 June 2017

Published online: 20 June 2017

\section{References}

1. Sobsey MD. Managing water in the home: accelerated health gains from improved water supply. Geneva: World Health Organization; 2002

2. Sobsey MD, Stauber CE, Casanova LM, Brown JM, Elliott MA. Point of use household drinking water filtration: a practical, effective solution for providing sustained access to safe drinking water in the developing world. Environ Sci Technol. 2008;42:4261-7.

3. Lin S, Huang R, Cheng Y, Liu J, Lau BLT, Wiesner MR. Silver nanoparticlealginate composite beads for point-of-use drinking-water disinfection. Wat Res. 2013;47:3959-65.

4. Nover DM, McKenzie ER, Joshi G, Fleenor WE. Assessment of colloidal silver impregnated ceramic bricks for small-scale drinking water treatment applications. Int J Serv Learn Eng, Humanitarian Eng Soc Entrep. 2013;8:18-35.

5. Ogunyoku TA, Nover DM, McKenzie ER, Joshi G, Fleenor WE. Point-of-use drinking water treatment in the developing world: Community acceptance, project monitoring and revision. Int I Serv Learn Eng Humanitarian Eng Soc Entrep. 2011;6:14-32.

6. Hadrup N, Lam HR. Oral toxicity of silver ions, silver-a review. Regul Toxicol Pharmacol. 2014;68:1-7.

7. World Health Organization. In: fourth edition, editor. Guidelines for Drinkingwater Quality. Geneva: World Health Organization; 2011.

8. East BW, Boddy K, Williams ED, Macintyre D, McLay AL. Silver retention, tota body silver and tissue silver concentrations in argyria associated with exposure to an anti-smoking remedy containing silver acetate. Clin Exp Dermatol. 1980;5:305-11.

9. Lee JH, Kim YS, Song KS, Ryu HR, Sung JH, Park JD, et al. Biopersistence of silver nanoparticles in tissues from Sprague-Dawley rats. Part Fibre Toxicol. 2013;10:1

10. Kim YS, Kim JS, Cho HS, Rha DS, Kim JM, Park JD, et al. Twenty-eight-day oral toxicity, genotoxicity, and gender-related tissue distribution of silver nanoparticles in Sprague-Dawley rats. Inhal Toxicol. 2008;20:575-83.

11. Li Y, Chen DH, Yan J, Chen Y, Mittelstaedt RA, Zhang Y, et al. Genotoxicity of silver nanoparticles evaluated using the Ames test and in vitro micronucleus assay. Mutat Res. 2012;745:4-10.

12. Magdolenova Z, Collins A, Kumar A, Dhawan A, Stone V, Dušinská M. Mechanisms of genotoxicity. A review of in vitro and in vivo studies with engineered nanoparticles. Nanotoxicology. 2014;8:233-78.

13. Kim HR, Kim MJ, Lee SY, Oh SM, Chung KH. Genotoxic effects of silver nanoparticles stimulated by oxidative stress in human normal bronchial epithelial (BEAS-2B) cells. Mutat Res. 2011;726:129-35.

14. Schneider K, Schwarz M, Burkholder I, Kopp-Schneider A, Edler L, KinsnerOvaskainen A, et al. "ToxRTool", a new tool to assess the reliability of toxicological data. Toxicol Lett. 2009;189:138-44.

15. Klimisch H-J, Andreae M, Tillmann U. A systematic approach for evaluating the quality of experimental toxicological and ecotoxicological data. Regul Toxicol Pharmacol. 1997;25:1-5.

16. Ordzhonikidze CG, Ramaiyya LK, Egorova EM, Rubanovich AV. Genotoxic effects of silver nanoparticles on mice in vivo. Acta Nat. 2009;1:99-101.

17. Tavares $P$, Balbinot F, de Oliveira HM, Fagundes GE, Venâncio M, Ronconi JV et al. Evaluation of genotoxic effect of silver nanoparticles (Ag-Nps) in vitro and in vivo. J Nanopart Res. 2012;14:1-7.

18. Chen YT, Wu JH, Tsai FJ, Chang YW, Hsu SH, Lin JJ, et al. Genotoxicity tests of poly (styrene-co-maleic anhydride)-coated silver nanoparticles in vivo and in vitro. J Exp Nanosci. 2015;10:449-57.

19. Awasthi KK, Awasthi A, Verma R, Soni I, Awasthi K, John PJ. Silver Nanoparticles and Carbon Nanotubes Induced DNA Damage in Mice Evaluated by Single Cell Gel Electrophoresis. Macromol Symp. 2015:357:210-7.

20. Gromadzka-Ostrowska J, Dziendzikowska K, Lankoff A, Dobrzyńska M, Instanes C, Brunborg G, et al. Silver nanoparticles effects on epididymal sperm in rats. Toxicol Lett. 2012;214:251-8.

21. OECD. In vivo mammalian alkaline comet assay. TG 489. OECD Guideline for the Testing of Chemicals. 2014 Available: http://www.oecd.org/env/test-no474-mammalian-erythrocyte-micronucleus-test-9789264224292-en.htm. Accessed 18 Jun 2017.

22. OECD. Mammalian erythrocyte micronucleus test. TG 474. OECD Guideline for the Testing of Chemicals, 2014. Available: https:/ntp.niehs.nih.gov/iccvam/ suppdocs/feddocs/oecd/oecd-tg489-2014.pdf. Accessed 18 Jun 2017.

23. Aktepe N, Kocyigit A, Yukselten Y, Taskin A, Keskin C, Celik H. Increased DNA Damage and Oxidative Stress Among Silver Jewelry Workers. Biol Trace Elem Res. 2015:164(2):185-91.

24. EFSA. Scientific opinion on the re-evaluation of silver (E174) as food additive. Eur Food Saf Authority. 2016:14(1):4364.

25. Samburg ME, Oldenburg SJ, Monteiro-Riviere NA. Antibacterial efficacy of silver nanoparticles of different sizes, surface conditions and synthesis methods. Nanotoxicology. 2011;5:244-53.

26. Warheit DB, Donner EM. Rationale of genotoxicity testing of nanomaterials: regulatory requirements and appropriateness of available OECD test guidelines. Nano. 2010:4:409-13.

27. OECD. Guidance document on revisions to OECD genetic toxicology test guidelines. November 30th, 2015, Organisation for Economic Co-operation and Development. http://www.oecd.org/env/ehs/testing/Draft\%20Guidance\% 20Document\%20on\%200ECD\%20Genetic\%20Toxicology\%20Test\% 20Guidelines.pdf. Accessed 18 Jun 2017.

28. Kovvuru P, Mancilla PE, Shirode AB, Murray TM, Begley TJ, Reliene R. Oral ingestion of silver nanoparticles induces genomic instability and DNA damage in multiple tissues. Nanotoxicology. 2015;9:162-71.

29. Rayner J, Skinner B, Lantagne D. Current practices in manufacturing locallymade ceramic pot filters for water treatment in developing countries. J Water Sanit Hyg Dev. 2013:3:252-61.

30. WHO. Results of Round I of the WHO International Scheme to Evaluate Household Water Treatment Technologies. Geneva: World Health Organization; 2016.

31. Froggett SJ, Clancy SF, Boverhof DR, Canady RA. A review and perspective of existing research on the release of nanomaterials from solid nanocomposites. Part Fibre Toxicol. 2014;11:1. 
32. Garboś S, Swięcicka D. Silver migration from silver-modified activated carbon applied as a water filtration medium in classic cartridges of jug filter systems. Food Addit Contam Part A Chem Anal Control Expo Risk Assess. 2012:29(11):1810-9.

33. Garboś S, Swięcicka D. Human exposure to silver released from silvermodified activated carbon applied in the new type of jug filter systems. Rocz Panstw Zakl Hig. 2013;64(1):31-6.

34. Moher D, Liberati A, Tetzlaff J, Altman DG. Preferred Reporting /tems for Systematic Reviews and Meta-Analyses: The PRISMA Statement. PLoS Med. 2009;6:e1000097.

35. Al Gurabi MA, Ali D, Alkahtani S, Alarifi S. In vivo DNA damaging and apoptotic potential of silver nanoparticles in Swiss albino mice. Onco Targets Ther. 2015;8:295-302.

36. Ghosh M, Manivannan J, Sinha S, Chakraborty A, Mallick SK, Bandyopadhyay $M$, et al. In vitro and in vivo genotoxicity of silver nanoparticles. Mutat Res Genet Toxicol Environ Mutagen. 2012;749:60-9.

37. Asare N, Duale N, Slagsvold HH, Lindeman B, Olsen AK, GromadzkaOstrowska J, et al. Genotoxicity and gene expression modulation of silver and titanium dioxide nanoparticles in mice. Nanotoxicology. 2016;10:312-21.

38. Dobrzyńska MM, Gajowik A, Radzikowska J, Lankoff A, Dušinská M, Kruszewski M. Genotoxicity of silver and titanium dioxide nanoparticles in bone marrow cells of rats in vivo. Toxicology. 2014;315:86-91.

39. Kim JS, Sung JH, Ji JH, Song KS, Lee JH, Kang CS, et al. In vivo genotoxicity of silver nanoparticles after 90-day silver nanoparticle inhalation exposure. Saf Health Work. 2011;2:34-8.

40. Awasthi KK, Verma R, Awasthi A, Awasthi K, Soni I, John PJ. In vivo genotoxic assessment of silver nanoparticles in liver cells of Swiss albino mice using comet assay. Adv Mater Lett. 2015;6(3):187-93.

41. Patlolla AK, Hackett D, Tchounwou PB. Genotoxicity study of silver nanoparticles in bone marrow cells of Sprague-Dawley rats. Food Chem Toxicol. 2015;85:52-60.

42. El Mahdy MM, Eldin TA, Aly HS, Mohammed FF, Shaalan MI. Evaluation of hepatotoxic and genotoxic potential of silver nanoparticles in albino rats. Exp Toxicol Pathol. 2015;67:21-9.

43. Katsnelson BA, Privalova LI, Gurvich VB, Makeyev OH, Shur VY, Beikin YB, et al. Comparative in vivo assessment of some adverse bioeffects of equidimensional gold and silver nanoparticles and the attenuation of nanosilver's effects with a complex of innocuous bioprotectors. Int J Mol Sci. 2013:14:2449-83.

\section{Submit your next manuscript to BioMed Central and we will help you at every step:}

- We accept pre-submission inquiries

- Our selector tool helps you to find the most relevant journal

- We provide round the clock customer support

- Convenient online submission

- Thorough peer review

- Inclusion in PubMed and all major indexing services

- Maximum visibility for your research

Submit your manuscript at www.biomedcentral.com/submit

) Biomed Central 